\title{
Influence of Information Sources on Awareness of Forestry-related Technology in Southwest Nigeria
}

\author{
* Adu, A. O. and ** Adekoya, A. E. \\ ${ }^{*}$ Forestry Research Institute of Nigeria, Ibadan. \\ ${ }^{* *}$ Department of Agricultural Extension and Rural Development, \\ University of Ibadan, Ibadan \\ E-mail: deboladeleadu@yahoo.com.
}

\begin{abstract}
Forestry-related technologies (FRTs) are practices to mitigate and ameliorate effects of environmental degradation resulting from agricultural production practices. However, inadequate sources of information on FRTs among farmers limit and hinder farmers' awareness of such technologies. This study investigated the interrelatedness of information sources and awareness of FRTs in Southwest Nigeria. Multi-stage sampling technique was used to randomly select respondents from Forestry Research Institute of Nigeria (FRIN) catchments areas in the study area. A total of 444 respondents were selected for the study. Data on information sources and awareness were collected using a structured interview schedule. Analysis involved use of descriptive statistics and Pearson product-moment correlation. Predominant sources of FRT information were forestry staff (95.5\%) and relatives (66.2\%). Most farmers (91.7\%) were aware of windbreaks, $89.9 \%$ each were aware of taungya and fuelwood production while $83.0 \%$ was aware of alley farming. Farmers' information sources is significantly related to their awareness of FRT ( $r=0.40, p<0.01)$. It was concluded that farmers' information sources affect their awareness of FRTs. It was therefore recommended that information sources on FRTs should be improved upon in order to enhance farmers' awareness of them.
\end{abstract}

Keywords: Farmers, Forestry-related technology, Information sources and Awareness.

\section{INTRODUCTION}

A forest is a large area of land covered with trees and other plants growing close together. It is a plant community, predominantly of trees or other woody vegetation, occupying an extensive area of land (Adams, 2007). The term forest is used to describe land with tree canopy or cover of not more than 10 percent of an area of 0.5 ha. Forests and tree resources have played an important role in household food security, especially during seasonal and emergency hardship periods. The importance of trees and tree products varies greatly from community to community. In the Sahelian region browse represents an estimated $30-40 \%$ of the dry season feed (Le Houerou, 1986). Forestry efforts have been known to substantially alter fundamental social, economic and political factors at the root of many food supply inequalities. It could be concluded that the answer to declining availability of food, income or employment lies in forest-based interventions. 
Forestry-related technologies (FRTs) are the practices devised to help address the problem of environmental hazard caused by disturbance of natural ecosystems. According to Adu (2005), forestry-related technology has been the most consistent driving force behind environmental development and it has contributed from one-half to two thirds of environmental amelioration over recent decades. In fact, they are fast becoming a mainstay of many interventions and at the same time, they are of importance to the nation's economy as the industries they support provide means of livelihood to the people while their products offer means of income and foreign exchange earnings. These conservation technologies have been readily and widely adopted by farmers as most of them primarily address on-farm issues, including reduced tillage for reducing erosion. Some of these technologies are woodlots development, taungya, home-gardens, alley cropping, plantation crops combination, apiculture, aqua forestry, borderline planting and protein banks. It should be noted that the adoption decisions of forestry-related technologies are more complicated than those for annual crops in that many costs and benefits of the practices are not obvious in the first few years (Onumadu, 2002). This is because of the long-term result of forestry. Farming systems are highly complex. A change in one part of the system tends to create a cascade of changes throughout the system and as such, though policy initiatives may be directed at one particular aspect of the farming system they may have consequences for the entire farming system (Kaine and Bewsell (2003). For instance, the introduction of a new technology may generate different benefits in different farming contexts and the resultant effect is different applications and adaptations of the technology.

A number of technologies have been generated and are available. However, its sustainability in terms of the farmers' awareness of such technologies and the sources of awareness has not been given adequate consideration. In Nigeria, especially in the Southwestern States, problems of discontinued use prevailed. This is as a result of inadequate awareness of the benefits accruable from some technologies. Marra et al., (2003) and Angba (2000) submitted that the awareness of the indigenous livelihood system is imperative to develop a sustained agricultural technology.

Various sources of information are used to disseminate agricultural technologies. Many findings revealed that younger, better-educated farmers have more contact with information sources and change agents than illiterate farmers (Onumadu, 2002). While it is lucidly stated that the acceptance of information or idea by individuals depends on the credibility of the source, Akinbode (1969) pointed out that the extent to which farmers use information sources could also be influenced by their socio-economic status. William et al., (1998) found significant positive relationship between mass media exposure and innovativeness. They also reported positive association between mass media exposure and opinion leadership in Columbia. Conversely, Rangaswamy et al. (1972) observed that personal sources such as friends, neighbors and relatives are the major sources of information accounting for 52 percent out of 12 selected sources of information in India.

When farmers could no longer have access to information about an innovation they have adopted, sustaining such innovation may be affected. Boardman (1990) emphasized that farmers must continue to have access to information systems to reassure them that the innovation they have adopted could be sustained. Moreover, the fact that forestry-related technology is mostly practiced by farmers within and 
around government reserves, farmers need to have up-to-date information in order to allay their fears of loosing their farmlands to the government once the innovation they adopted is thriving, thereby increasing their level of poverty (Adu, 2005). As such, the development of an enduring FRT, which can attract maximum participation of target group, will require a virile source of information.

It is against this backdrop that an assessment of the information sources available to farmers and their awareness of Forestry-related Technologies is very crucial, as this is an important factor which will aid an appreciation of the overall performance of FRTs and thus help in developing an effective people-oriented FRT programme.

\section{Hypothesis}

There is no significant relationship between respondents' sources of information and their awareness of FRTs.

\section{METHODOLOGY}

The area of study is southwest Nigeria. It lies between Latitudes $5^{\circ}$ and $9^{\circ} \mathrm{N}$ and has an area of $114.271 \mathrm{~km}^{2}$ representing $12 \%$ of the country's total land area. It includes Edo, Delta, Ekiti, Lagos, Ogun, Ondo, Osun, and Oyo States. The study population consists of all farmers in Catchment areas of Forestry Research Institute of Nigeria (FRIN) in Southwest Nigeria.

Multi-stage sampling technique was used in selecting samples for the study. First, four states in Southwest Nigeria (Oyo, Ogun, Ondo and Edo) having FRIN stations and sub-stations (Onigambari, Olokemeji, Ore and Sakpoba) were purposively selected. Second, in each of the selected areas, $50 \%$ of the villages were randomly selected. At Onigambari (Oyo State), six out of the twelve villages were randomly selected. At Olokemeji (Ogun State), five out of the ten villages in the area were randomly selected. At Ore (Ondo State), five out of the ten villages were also randomly selected while at Sakpoba (Edo State); six out of the twelve villages were randomly selected. Finally, ten percent $(10 \%)$ of the registered farmers in all the selected villages were then randomly selected and these amounted to 444 respondents.

Both descriptive and inferential statistics were used to analyse the data collected. Descriptive statistics used include frequency count and percentages. Frequency table was used to show respondents' personal characteristics and information sources for each technology while inferential statistics-Pearson product moment correlation was used to determine the relationship between information sources and awareness of forestry-related technologies in the study area. 
TABLE 1: Showing sampling procedure and sample size

\begin{tabular}{|c|c|c|c|}
\hline Areas/States & $\begin{array}{c}\text { Selected } \\
\text { Village(s) }\end{array}$ & $\begin{array}{l}\text { Total Number of } \\
\text { Registered } \\
\text { Farmers } \\
\end{array}$ & $10 \%$ Sample \\
\hline \multirow{7}{*}{$\begin{array}{l}\text { Onigambari } \\
\text { (Oyo State) }\end{array}$} & Gambari & 230 & 23 \\
\hline & Busogboro & 83 & 8 \\
\hline & Adebayo & 182 & 18 \\
\hline & Dalley & 102 & 10 \\
\hline & Longe & 321 & 32 \\
\hline & Karangbada & 19 & 2 \\
\hline & Total & 937 & 94 \\
\hline \multirow{6}{*}{$\begin{array}{l}\text { Olokemeji } \\
\text { (Ogun State) }\end{array}$} & Olokemeji & 408 & 41 \\
\hline & Akintoye & 52 & 5 \\
\hline & Alade & 270 & 27 \\
\hline & Ogunsile & 580 & 58 \\
\hline & Olowo & 174 & 17 \\
\hline & Total & 1484 & 148 \\
\hline \multirow{6}{*}{$\begin{array}{l}\text { Ore } \\
\text { (Ondo State) }\end{array}$} & Ogbeni & 100 & 10 \\
\hline & PWD (People & 202 & 20 \\
\hline & Work and Die) & 191 & 19 \\
\hline & Asejire & 155 & 16 \\
\hline & $\begin{array}{l}\text { Oniseere } \\
\text { Adewinle }\end{array}$ & 283 & 28 \\
\hline & Total & 931 & 93 \\
\hline \multirow{7}{*}{$\begin{array}{l}\text { Sakpoba } \\
\text { (Edo State) }\end{array}$} & Sakpoba & 418 & 42 \\
\hline & Onah & 102 & 10 \\
\hline & Avbeh & 91 & 9 \\
\hline & Iguemokhua & 204 & 20 \\
\hline & Evbuosa & 180 & 18 \\
\hline & Evbuarhue & 96 & 10 \\
\hline & Total & 1091 & 109 \\
\hline Grand Total & 18 & 4443 & 444 \\
\hline
\end{tabular}

\section{RESULTS AND DISCUSSION}

Table 2 shows that most of the respondents (33.1\%) fell within $40-49$ years age bracket an indication that more able-bodied people are involved in farming especially Forestry, which has a tedious nature, requires that a farmer is young, agile and able bodied so as to be able to withstand the pressure of work. However, only $18.2 \%$ of the respondents were 60 years and above. This may be due to the tedious nature of farming which makes it impossible for old people to stay away from it. The mean age of respondents was 47 years ranging from 20-70 years. This finding supports that of Ige (2000) and Adu (2000) that there was a predominance of medium aged people among the farming population. 
Journal of Agricultural Extension

Vol. 12 (1) June, 2008

TABLE 2: Distribution of respondents based on age

\begin{tabular}{|l|c|c|}
\hline Age & Frequency & $\%$ \\
\hline $20-29$ & 111 & 25.0 \\
\hline $30-39$ & 39 & 8.8 \\
\hline $40-49$ & 147 & 33.1 \\
\hline $50-59$ & 66 & 14.9 \\
\hline 60 and above & 81 & 18.2 \\
\hline
\end{tabular}

$$
\overline{\mathrm{X}} \text { Age }=47 \text { years }
$$

\section{Sex of Respondents}

Figure 1 indicates that $64.0 \%$ of the respondents were males while only $36.0 \%$ were females. This shows that there is gender imbalance in agricultural practice and it also confirms the assertion of Ipaye (1995) and Adu (2000) that men dominate the present farming population in southwest Nigeria. This might be because women do not have land ownership rights except in cases of inheritance from parents or husbands. The implication of this is that only few women are involved in FRT utilization.

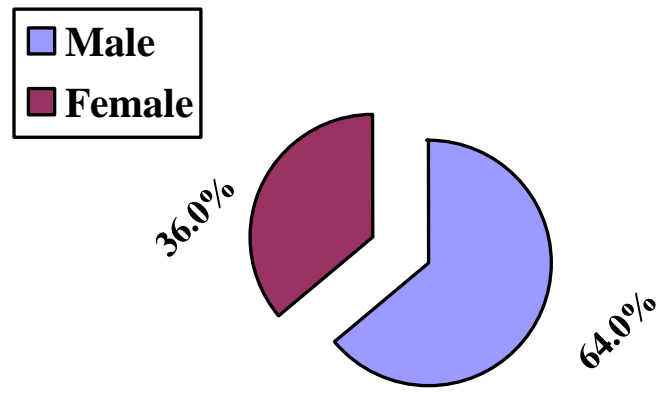

Fig.1: Showing Respondent's Sex

\section{Respondents' educational background}

Education is an essential factor for effecting desirable changes in attitude, skills and knowledge of individuals (Odebode, 1997). Table 3 indicates that a total of $37.1 \%$ of the respondents had no formal education - an indication of the low level of formal education in rural communities. A marked difference was observed between respondents with primary school education (42.7\%) and those with secondary school education $(18.7 \%)$. This could be a function of poverty in the area. The effect of education on awareness of FRTs is that it broadens the mind and widens the scope of the individuals concerned. There can sometimes be relationship between education and the awareness of forestry-related technologies. According to Kilpatrick (2000), beneficial innovations tend to be adopted more quickly by farmers with higher levels of education as they are often exposed to various information sources. From the above, it could be deduced that educational background will aid easy understanding of what forestry-related technology is about and the decision to use it. 
TABLE 3: Showing respondents' educational background

\begin{tabular}{|l|c|c|}
\hline Educational Background & Frequency & \% \\
\hline No formal & 164 & 37.0 \\
\hline Primary & 190 & 42.8 \\
\hline Secondary & 83 & 18.7 \\
\hline Tertiary & 7 & 1.5 \\
\hline Total & $\mathbf{4 4 4}$ & $\mathbf{1 0 0 . 0}$ \\
\hline
\end{tabular}

\section{Sources of Information}

Table 4 reveals that majority of the respondents $(97.5 \%)$ got information on fuelwood production from relatives. This may be because fuelwood is used among rural populations for heating and also, it is one of the by-products of woodlot development, and as such it is easily passed on to on-coming generations. Only $1.3 \%$ of the respondents received information on fuelwood production from forestry staff and contact farmers. This is an indication of the importance of the technology to respondents' household energy consumption. Thus confirming the assertion of Ige (2000) that fuelwood serves as the main source of energy for rural households and many small-scale industries. Furthermore, the Table shows that $91.0 \%$ of the respondents got information on woodlot development from forestry staff. Receiving information directly from forestry staff, suggests the tendency that information will be well understood and this will aid the use of FRTs. Only $1.0 \%$ got information on the technology from the media. Table 4 further shows that about $80.0 \%$ respondents received information on use of trees in soil conservation from forestry staff. This is because tree planting has long gestation period and thus, requires that farmers be persuaded and convinced about it. Only $15.5 \%$ respondents received information from relatives while $3.2 \%$ and $1.5 \%$ received information from contact farmers and media respectively. Fifty two percent of the respondents received information on use of improved fallow from forestry staff and this was closely followed by relatives with $32.0 \%$. Contact farmers followed this with $26.0 \%$ respondents while only $1.0 \%$ got information on improved fallow from the media. Also, Table 4 reveals that $87.0 \%$ respondents received information on erosion control from relatives. It could be deduced that the technology, being an age-long practice was passed down to them by their forefathers.

Generally, the result shows that the respondents obtained more information on forestry-related technologies from forestry staff, which could be due to the presence of FRIN sub-stations and the states forestry departments in the area. This was closely followed by relatives, an indication that most of the technologies are age-long practices engaged in by farmers. However, the result reveals that none of the respondents received information on any of the technologies from agricultural extension agents because agricultural extension agents do not disseminate forestry information (Obibiakwu and Hurst, 1977; Anigwe 1990; Abu and Afeyodion, 2000; Adeyemo, 2003 and Adu et al, 2004). DESA (1999) submitted that relatively little attention has been given to the need for increased forestry-related technology diffusion to the end beneficiaries through extension workers. The source through 
Journal of Agricultural Extension

Vol. 12 (1) June, 2008

which farmers get to know of an innovation will influence awareness, perception, use and continued-use of such technology. It can be presumed that where there is intense communication and sharing of knowledge, the emergence of use would be promoted. (Shih and Venkatesh, 2004). 


\section{Journal of Agricultural Extension}

Vol. 12 (1) June, 2008

TABLE 4: Information Sources for FRTs

\begin{tabular}{|c|c|c|c|c|c|c|c|c|c|c|}
\hline \multirow[b]{2}{*}{ Technologies } & \multicolumn{2}{|c|}{ Media } & \multicolumn{2}{|c|}{ Extension agents } & \multicolumn{2}{|c|}{ Forestry staff } & \multicolumn{2}{|c|}{ Contact farmers } & \multicolumn{2}{|c|}{ Relatives } \\
\hline & Frequency & $\%$ & Frequency & $\%$ & Frequency & $\%$ & Frequency & $\%$ & Frequency & $\%$ \\
\hline Alley Faming & 6 & 1.5 & - & - & 370 & 91.6 & 6 & 1.5 & 22 & 5.4 \\
\hline Woody Perennial for Shelter & 3 & 1.0 & - & - & 112 & 35.0 & 2 & 0.6 & 203 & 63.4 \\
\hline Windbreaks & 6 & 1.5 & - & - & 71 & 17.4 & 26 & 6.4 & 304 & 74.7 \\
\hline Borderline Planting & 9 & 2.0 & - & - & 125 & 28.2 & 10 & 2.3 & 300 & 67.6 \\
\hline Taungya & 4 & 1.0 & - & - & 315 & 81.2 & 51 & 13.1 & 18 & 5.0 \\
\hline Woodlot Development & 3 & 1.0 & - & - & 291 & 91.0 & 6 & 2.0 & 21 & 7.0 \\
\hline Fruit trees raising & 1 & 0.4 & - & - & 212 & 80.3 & 5 & 2.0 & 46 & 17.4 \\
\hline Trees in soil conservation & 5 & 1.5 & - & - & 274 & 80.0 & 11 & 3.2 & 53 & 15.5 \\
\hline Improved fallow & 5 & 1.0 & - & - & 259 & 52.0 & 75 & 26.0 & 159 & 32.0 \\
\hline Roadside planting & 7 & 4.8 & - & - & 125 & 85.0 & 4 & 3.0 & 11 & 7.5 \\
\hline Erosion control & 1 & 0.3 & - & - & 30 & 10.0 & 11 & 4.0 & 309 & 87.0 \\
\hline Fuelwood production & - & - & - & - & 5 & 1.3 & 5 & 1.3 & 389 & 97.5 \\
\hline
\end{tabular}




\section{Awareness of FRTs}

Table 5 shows that $83.3 \%$ of the respondents were aware of alley farming. This may be because alley farming improves economic stability, increases cash flow and enhances sustainable agricultural system as it enables farmers to produce food crops and at the same time enhances good performance of crop yield as the tree components are effective nutrient pumps, which bring minerals from the lower soil profile to the surface. (Hodge, et al., 2002). Moreover, $87.2 \%$ of the respondents in the area were aware of Taungya. This may be because it was the initial technology introduced to farmers in the area when the plantations were to be established and as such, respondents had gotten used to the technology.

The Table also shows that $91.7 \%$ of the respondents were aware of windbreaks. This is expected, as respondents may need to plant trees in order to shield either crops or buildings from heavy wind or rainstorm. This finding agrees with the work of Vanclay (2002) that planting trees around farms serves as windbreaks for the crop as well as prevention of soil erosion. This is necessary in order to combat the transition of the southwestern Nigeria from rain forest to derived Savannah. About $91.9 \%$ of the respondents were aware of borderline planting. This may be because it is an age long practice which farmers use for land or boundary demarcation. Furthermore, Table 5 reveals that a larger percentage of the respondents $(89.2 \%)$ were aware of fuelwood production. This is an indication of the wide usage of fuelwood as the major source of energy by rural households. Sixty eight percent of the respondents were aware of woodlot development while the remaining $31.1 \%$ respondents were not aware of the technology. For trees in soil conservation, $75.5 \%$ claimed awareness of the technology. This may be because it is an age long practice. Ogunsanwo et al. (2003) submitted that respondents value the usefulness of trees in soil reclamation and attested to its ability to replenish the soil. Only $24.5 \%$ were not aware of the technology. However, majority of the respondents $(70.3 \%)$ were not aware of roadside planting. The few $(29.7 \%)$ who were aware of the technology claimed they had either at one time or the other worked with Forestry Research Institute of Nigeria or parastatals that are into environmental beautification. Roadside planting is largely an environment beautification project, which has little or nothing to do with farming activities, and as such, it is not out of point for farmers not to be aware of the technology. The mean awareness score was 10.18 .

Generally, respondents' awareness of FRTs in the study area could be adduced to the professional advice and expertise that are likely to have been impacted to the farmers by staff of FRIN and States Forestry Department in the area and it is expected that if awareness is high, adoption rate is also expected to be high. It should be noted that awareness does not just mean that an innovation exists but that it is potentially of practical relevance to the farmers (Barr and Cary, 2000 and Rogers, 2003). Being aware of an innovation is not enough but farmers must have access to such innovations. According to Adu (2005), the first stage towards the adoption of an innovation is to become aware that it exists. 
TABLE 5: Respondents' Awareness of Forestry-related Technologies

\begin{tabular}{|l|c|c|c|c|}
\hline \multirow{2}{*}{\multicolumn{1}{|c|}{ Technologies }} & \multicolumn{2}{c|}{ Aware } & \multicolumn{2}{c|}{ Not aware } \\
\cline { 2 - 5 } & Frequency & Percentage & Frequency & Percentage \\
\hline Alley Farming & 370 & 83.3 & 74 & 16.7 \\
\hline Woody Perennial & 295 & 66.4 & 109 & 24.5 \\
\hline Windbreaks & 407 & 91.7 & 27 & 6.1 \\
\hline Erosion control & 307 & 69.1 & 27 & 6.1 \\
\hline Borderline planting & 408 & 91.9 & 36 & 8.1 \\
\hline Taungya & 387 & 87.2 & 77 & 17.3 \\
\hline Woodlot development & 306 & 68.9 & 128 & 31.1 \\
\hline Fruit tree raising & 239 & 53.8 & 205 & 46.2 \\
\hline Trees in soil \\
conservation
\end{tabular}

$X$ Awareness Score $=10.18$

The result of correlation analysis shows that a significant relationship exists between information sources and awareness of FRT ( $r=0.40, p<0.01)$. The null hypothesis is therefore rejected. This suggests the importance of information sources to awareness. If the source of information on FRTs is not well harnessed, it may not achieve the desired objective of creating awareness. For instance, the media (radio) and the extension agents are important sources in creating awareness (Azeez, 2002). However, in this study, none of the respondents got information on FRTs from extension agents (Table 2). Also, it would be expected that contact farmers should be good sources of information but findings of this study reveal that only a few respondents got information from contact farmers while most of the respondents obtained their information from forestry staff. This is an indication of inadequate sources of information.

\section{CONCLUSION}

From the findings of this study, it could then be deduced that majority of the respondents were males, agile and had no-formal education. The major sources of FRT information were forestry staff and relatives. Based on these findings, it was therefore recommended that information dissemination on FRTs should not be left to FRIN alone, but it should be a collaborative effort of the ADPs and the extension division of forestry-based organizations (FRIN, State Ministries of Forestry, NGOs etc). Moreover, technology transfer, particularly FRT transfer, should be viewed as a "total system" that includes both products and services and development of human capacities, information networks and organizations and as such, attention should be focused on the provision of adequate information sources to create awareness in farmers and other end users. Finally, meetings should be held with farmers who had exhibited low awareness of FRTs in order to create in them the awareness. 


\section{References}

Abu J.E. and Afeyodion, D. (2000): The Role of Extension in Agricultural Development. AGRICOM Vol 1(1) .10 pp.

Adams, D. L. (2007): "Forest". Microsoft Student (DVD). Redmond, WA: Microsoft Corporation, 2006.

Adeyemo, T.O. (2003): Networking: A management strategy for sustainable community forestry. Proceedings of the $29^{\text {th }}$ FAN Conference on Community Forestry and Stakeholders' Participation in Sustainable Development. pp 269274

Adu, A.O. (2000): Farmers Constraints to Feedback provision or Forestry - related Technologies in three selected states of South Eastern Nigeria Unpublished M.Sc. Thesis in the Department of Agricultural Extension and Rural Development, Ibadan. $106 \mathrm{pp}$

Adu, A.O. (2005): Socio-Economic Impact of Forestry-Related Technologies Utilization Among Farmers in South West Nigeria. Unpublished Seminar Paper in the Department of Agricultural Extension and Rural Development, University of lbadan, $48 \mathrm{pp}$.

Adu, A.O., Famuyide, O.O., Adejoba, O.R. and Adeogun, M.O. (2004): Assessment of Extension Service in Forestry Establishments in Ogun State.Paper Presented at the $9^{\text {th }}$ Annual Conference of the Agricultural Extension Society of Nigeria, Obafemi Awolowo University, Ile Ife. March 14-17. 10pp

Akinbode, I.A. (1969): Relationship between the socio-economic characteristics of farmers in British Columbia and their contacts with district agriculturalist. Unpublished MS Thesis. University of Columbia .

Angba, A.O. (2000): Determinants of sustained use of selected Technologies Recommended to farmers to by Cross River State Agricultural Development Programme (ADP). Unpublished Ph.D Thesis in the Department of Agricultural of Extension and Rural Development. 189 pp

Anigwe, O. F. (1990): Farm Radio Listenership and Agricultural Knowledge: A Case Study of farmers in Akinyele Local Government Area of Oyo State, Nigeria: An Unpublished M. Sc Degree Thesis, Department of Agricultural Extension, University of Ibadan.

Azeez, I.O. (2002): Evaluation of media mix for disseminating forest conservation information in South Western Nigerian. Ph.D Thesis submitted to the Faculty of Agriculture and Forestry, University of Ibadan, Nigeria. $230 \mathrm{pp}$

Barr, N. and Cary, J. (2000): 'Influencing improved natural resource management on farms: A guide to factors influencing the adoption of sustainable natural resource management practices.' Bureau of Resource Sciences, Canberra.

Boardman, J., Lan, F. and John, D. (1990): Soil erosion on Agricultural Land. London: John Wiley (eds.). 15pp

Hodge, S., Garette, H.E and Brytton, J. (2002): Alley Cropping: An Agroforestry Practice. Agroforestry Notes. 
Ige, S.O.O. (2000): Perceived Benefits and use of Agro Forestry Practices in Derived Savannah and Rainforest zones of Oyo State, Nigeria Unpublished Ph.D Thesis in the Department of Agricultural Extension and Rural Development. $197 p p$.

Ipaye, G.A: (1995): Analysis of Role Performance of Contact Farmers in Training and Visit Extension System of Lagos State Agricultural Development Programme (ADP). An Unpublished Ph.D Thesis in the Department of Agricultural Extension Service, University of Ibadan, Ibadan. 209 pp

Kaine, G. and Bewsell, D. (2003): Are market research and extension complementary? Proceedings of the 18th Annual Conference of the Association of International Agriculture and Extension Education, Durban, South Africa, May.

Kilpatrick, S. (2000): Education and training: impacts on farm management practice. Journal of Agricultural Education and Extension 7, 105-116

Marra, M., Pannell D.J. and Abadi Ghadim, A. (2003): The economics of risk, uncertainty and learning in the

adoption of new agricultural technologies: Where are we on the learning curve? Agricultural Systems 75, 215-234.

Obibiakwu, L.O. and Hurst, G. D. (1977): Effective Method s for Influencing Agricultural Modernization among Pre-literate Communities. Journal of Rural Economics and Sociology. Vol.11, No 1. 107 pp

Odebode, S.O. (1997): Appropriate Technology for Rural Women in the Processing of Cassava and Soyabean in Oyo State, Nigeria. A Ph.D. Thesis Submitted to the Department of Agricultural Extension Services. University of Ibadan. 229pp.

Ogunsanwo, O.Y., Ajala, O.O. and Sanusi, M.A. (2003): Gliricida Sepium (JACQ) steud: A potential species for community woodlot development in Nigeria. In: Community Forestry and Stakeholders Participation in Sustainable Development. Proceedings of the $29^{\text {th }}$ Annual Conference of the Forestry Association of Nigeria held in Calabar, Cross River State, Nigeria. $6^{\text {th }}-11^{\text {th }}$ October, 2003 .pp 309-314

Onumadu, F.N. (2002): Determinants of Adoption of Agroforestry Practices by SmallScale Farmers in Katsina State, Nigeria. Unpulished Ph.D Thesis, Department of Forest Resources and Management, Unversity of Ibadan, Ibadan. 259pp

Rangaswamy, R.; Ramazany, A.S. and Guruswami, P.A. (1972): India Changing Farmers. India: Kitale, $238 \mathrm{pp}$

Rogers EM (2003) 'Diffusion of innovations.' $5^{\text {th }}$ ed. (Free Press: New York)

Shih, C.F. and Venkatesh A. (2004): Beyond adoption: Development and application of a use diffusion model. Journal of Marketing, 68, pp 59-72.

United Nations Department of Economic and Social Affairs (DESA) (1999): Transfer of environmentally sound technologies to support sustainable forest management. United Nations Economic and Social Council Intergovernmental Forum on Forests. Geneva. 24 August-4 September 1998.United NationsE/CN.17/IFF/ 1998/4. Posted on 5 December 1999. 
Journal of Agricultural Extension

Vol. 12 (1) June, 2008

Vanclay, F. (2002): Conceptualising Social Impacts. Environment Assessment Review 22: $183-211$

William, A.H., Stansfied, S.D., Whiting, G.C and Senining, L. (1998): Patterns of diffusing in rural Brazil. Report of Phase 111 Diffusion of Innovation in rural Society, Michigan, USA. Michigan State University Research Report 10, 115 pp 